\title{
The Future of English and Its Varieties: An Applied Linguistic Perspective
}

\author{
Abdelrahman Abdalla Salih ${ }^{1}$ \\ ${ }^{1}$ Department of English Language and Literature, College of Arts and Applied Sciences, Dhofar University, \\ Salalah, Sultanate of Oman \\ Correspondence: Abdelrahman Abdalla Salih, Department of English Language and Literature, College of Arts \\ and Applied Sciences, Dhofar University, Salalah, Sultanate of Oman.
}

Received: February 20, 2021

Accepted: March 10, 2021

Online Published: March 12, 2021

doi: $10.5539 /$ elt.v14n4p16

URL: https://doi.org/10.5539/elt.v14n4p16

\begin{abstract}
In recent years, the rapid growth and unprecedented dominance of the English language has transformed the world's linguistic ecology and promoted anxiety and debates about its future. The language has developed into a leading international lingua franca used by millions of speakers in different linguistic and cultural contexts worldwide. This paper examines an applied linguistic conceptual interest concerning the future of English and its varieties in light of its current status, the challenges it experiences, and the conspicuous threats to half of the world's languages. The paper draws on the significance of broadening the study of the English language history by examining the linguistic consequences associated with its changes and the users' experience, expectations and attitudes. The study also calls for a better understanding of the features of lesser-known English varieties and the less researched domains of its use.
\end{abstract}

Keywords: global English, language change, the future of English, varieties of English

\section{Introduction}

This paper examines conceptual interest in English's global proliferation and the possible scenarios that await this language and its varieties from an applied linguistic perspective. It is an attempt to explore the future of English in light of the rise and dominance of the language in the global linguistic arena. The English language's unprecedented triumph is a linguistic phenomenon that has left far-reaching consequences and implications in various fields and activities. The English language changes are not mere modifications of the language's linguistic system but a process that made the language a key player in changing the world's linguistic reality. Thus, the rise of English has created an intricate setting that reflects issues related to the relations with different world languages, linguistic realities, various sociolinguistic phenomena, and language pedagogy. Linguists believe that "There is an urgent need for documentation and analysis of the world's changing language landscape, and for informed advice" (Cook, 2003, pp. 29-30).

The history of language shows that human languages grow, change, prosper, or extinct. The process of change during the linguistic evolution journey of any living natural language becomes a mandatory ticket into the world of survival and continuity. Moreover, historians of language, including English, argue that "It is a convenient figure of speech to speak of languages as living or dead" (Baugh \& Cable, 2002, p. 2) based on the language's ability to change and deal with different circumstances and factors. The concept "Language change," as a subject matter of historical and comparative linguistics research, is "change in a language which takes place over time" (Richards, \& Schmidt, 2002, p. 287). It is about the what and when aspects of modification that occur in the linguistic system of a language as a result of specific factors of various types and nature. Change is a natural law that applies to all living things, including the constantly-changing human language (Trask, 2010, 1994). Living languages are then in a constant state of change because "one of the eternal truths about living languages is that they all change" (Winkler, 2007, p. 197). Thus, "It's no secret that languages change over the years" (Finegan, 2004, p. 446). Change in a language is inevitable, and all its linguistic aspects are subject to change because linguists report that "All parts of the grammar are subject to change over the course of time - the phonological, morphological, syntactic, and semantic components may be affected" (Formkin, Rodman, \& Hyams, 2011 , p. 489). The metaphor of biological evolution extends to human linguistic and communication systems to suggest that any living language needs to change to stay alive, grow and meet its speakers' needs. Thus, surviving and 
changing are two faces of a coin in the context of growth for any natural language. When a language stops changing and growing, it faces extinction or disappearance, putting its speakers at risk of losing their identity as well. Thus, language death is the other cost a language pays when it fails to change and grow. For instance, historical and comparative linguistics teaches us that "Classical Latin is a dead language because it has not changed for nearly 2,000 years" (Baugh \& Cable, 2002, p. 2).

On the other hand, for those languages which can grow and change, the story is entirely different. According to Cook (2003), "While the world's largest languages, such as Chinese, English, Hindi, Spanish, and Arabic, have hundreds of millions of speakers and are frequently used beyond their homeland", and have different forms of use, "the majority of the world's languages are much smaller, some with only a few hundred speakers" (p. 23). This painful reality becomes daunting when we come to know that "Most of the world's languages have never been written down anywhere or scientifically described" (Harrison, 2007, p. 3). Moreover, "smaller languages are confined to restricted areas and specific ethnic groups, and are often vulnerable" (Cook, 2003, pp. 23-24) to extinction.

The most recent estimates show us that there are around 6,000 different languages spoken around the world and that "548 languages with fewer than 99 speakers", according to Harrison, "make up nearly one-tenth of the world's languages, and all are faced with almost certain disappearance" (p. 4). Thus, the process of language endangerment is another variable that further complicates the disequilibrium in the global linguistic situation. Linguists predict that half of the world's languages are susceptible to extinction by the end of the millennium (Harrison, 2007; Cook, 2003) due to various reasons and factors. This prediction draws a gloomy picture marred by uncertainty in the linguistic situation of the world, which calls for taking serious measures to stop the looming danger over the most precious human heritage. There is a pressing moral obligation for rectifying the imbalanced global linguistic ecology, especially with the rise of global English. Calling for assessing the rapid growth of English, Cook (2003) argues that "We need to consider whether the current situation is unprecedented, whether it has produced a new set of language related problems (whether, for example, the spread of international English is implicated in the decline and disappearance of other languages" (p. 30). Investigating the consequences of the spread and dominance of global English extends the need for examining the possible fate it will face in the future. The crux of the matter is that English language today presents a very complex linguistic reality of a single language that has developed, extended, and produced varieties of different forms and functions. The global dispersion of the English language is a linguistic phenomenon so much present in any prediction of its future. Assessing the changing global linguistic ecology in light of English's internationalization may provide some insights into the future of the entire global linguistic situation. In this context, the present study specifically strives to express an applied linguistic conceptual interest by addressing the possible scenarios that await the English language and its varieties tomorrow.

\section{English Language: A Journey of Remarkable Change and Growth}

\subsection{Old English}

The arrival of the Germanic Tribes in the British Isles in the Fifth Century BC marked the birth of the English language (Culpeper, 2005; Baugh \& Cable, 2002), an event that eventually influenced the linguistic situation in the world. Since its birth, the English language develops a spectacular historical linguistic profile that captures the interest and imagination of researchers and linguists concerned with the development of the language. Assuming different conceptual orientations, including historical linguistics, researchers such as (Millward, 2012; Algeo \& Pyles, 2010; Baugh \& Cable, 2002; Crystal, 2002, 1997; Brutt-Griffler, 2002, among others) produced impressive volumes of influential work that focused on documenting the factors behind the change and growth of the English language and their linguistic consequences on the language system. The diachronic and synchronic approaches employed in the description of English provided rich data on the linguistic development of the language in the areas of sounds, grammar, and vocabulary.

The English language historians have comfortably divided its history into three main overlapping periods: Old English, Middle English, and Modern English. According to Finegan (2004), "Because languages change continuously, any division into historical stages or periods must be somewhat arbitrary" (p. 505). For instance, Winkler (2007) suggests that "The periods of Old, Middle and Modern English are arbitrary divisions bounded by important political or cultural events" (p. 174). In the same vein, Baugh \& Cable (1993) remark that "Like all divisions in history, the periods of the English language are matters of convenience and the dividing lines between them purely arbitrary" (p. 50). These divisions are arbitrary and less controversial than other issues concerning the language, such as its recent development and the relations with other languages in the world, in the sense that there is somewhat consensus among researchers regarding the former point. Thus, the continuous 
ability of the language to change suggests that "A better way to look at the shifting varieties of English is to think of a continuum of overlapping varieties all of which have been changing but to different degrees" (Winkler, 2007, p. 147). The extensive investigations of researchers on the English language's linguistic developments throughout the three periods attribute the change of the language to numerous historical, technological, scientific, social, and cultural events, each of which had its linguistic consequences on the language.

The history of the English language has shown that one of the remarkable features of this language is its flexibility and ability to change and grow. Since its introduction into the British Isles in the fifth century, the "English language has undergone such change in the course of time that one cannot read Old English without special study" (Baugh \& Cable, 2002, p. 53). The fact that "Old English will inevitably seem to the modern reader a crabbed and difficult language full of needless complexities" (Algeo \& Pyles, 2010, p. 93) is due to the highly inflectional system, strange characters, and intricate spelling style the language had. Old English was described as a synthetic language that is loyal to its Germanic-rooted vocabulary.

\subsection{Middle English}

English transformed its highly inflectional system and purely Germanic vocabulary as it entered the Middle English period when it experienced extensive cultural and linguistic transformation. Baugh and Cable (2002) described Middle English as a period of significant change and social and linguistic instability. The researchers observed that "The Middle English period (1150-1500) was marked by momentous changes in the English language, changes more extensive and fundamental than those that have taken place at any time before or since" (p. 158). It is about this eventful period that researchers were amazed "How had the language managed to survive the French invasion" (Crystal, 2002, p. 191). In the Middle English period, Chamonikolasová (2014) observed that "The development of the English language was strongly influenced by political changes following the Norman Conquest" (p. 46) "—an event more far-reaching in its effects on English" (Algeo \& Pyles, 2010, p. 113) "than any other in the course of its history" (Baugh \& Cable, 2002, p. 108). Looking at the source of effects brought to English during the Middle English period, Crystal (2002) remarked that "The main influence on English was, of course, French - the language introduced to Britain by the Normans" (p. 190), making language contact an inevitable linguistic reality.

The introduction and consequent dominance of French resulted in the fluctuation and oscillation in the status and use of the English language throughout the period between the decline in using English as a national language by all English people and the reestablishment and then total triumph and control towards the end of the period (Winkler, 2007). During this period, English underwent considerable changes at varying degrees in its cultural and linguistic systems and most of its inflections were leveled and its Germanic vocabulary transformed remarkably. According to Baugh and Cable (2002), "While the loss of inflections and the consequent simplification of English grammar were thus only indirectly due to the use of French in England, French influence is much more direct and observable upon vocabulary" (pp. 167-168).

Moreover, one of the remarkable features of Middle English is its dialectical variation all over the country (Algeo \& Pyles, 2010) as a direct result of the Norman Conquest. The direct aftermath of the Norman long-term ruling was the richness and diversity of dialects, which was a conducive atmosphere for the birth of modern standard English. Baugh and Cable (2002) remarked that "out of this variety of local dialects there emerged toward the end of the fourteenth century a written language that in the course of the fifteenth won general recognition and has since become the recognized standard in both speech and writing" (p. 192). The rise of modern standard English towards the fourteenth century was an indication of the different direction that the language change process was taking English to. The modern standard English variety we speak today was then the result of the interaction among the dialects spoken around London, which added to its economic, political and cultural importance. Historians of English described "London speech-essentially East Midland" (Algeo \& Pyles, 2010, p. 119) as bland and flexible compared to the other regional dialects, namely, Northern, West Midland, and Southern. This feature of having a flexible linguistic system together with the dialect's strategic geographical position and larger population made the rise of standard English possible. The remarkable ability for change that signifies English even at the modern time is not a new phenomenon. Since the origins of standard modern English reflected such flexibility for change, the ability to adapt to different influences at present might be attributed to the flexible features inherited from its roots during the Middle English period.

\subsection{Modern English}

In the Modern English Period, which Millward and Hayes (2012) described as a "highly eventful period" (p. 219), the English language continued to display an extraordinary ability to benefit from all the influences, whether internal or external and invest them in developing its inner and outer history. In describing Modern 
English, Davies (2013) remarked that "Modern English is most simply defined as a third stage in the history of the language, beginning around 1450 (the first two being the Old English and Middle English stages)" (p. 28). Linguists divided this stage into 'Early Modern English' and 'Late Modern English.' According to Algeo and Pyles (2010), "The early Modern period was transformative for both England and the language" (p. 139) due to the impact of a set of technological, cultural, and scientific events that happened and had significant linguistic consequences on the language. Davies (2013) added that "During the Early Modern English phase a number of highly significant and liberating changes took place in English society that were to have a profound effect on the way the language was to be used and regarded" (p. 28).

Linguists reported that the events responsible for the changes brought to the English language during this period were: the printing press, the industrial revolution, the Protestant Movement, the Renaissance, the socioeconomic change caused by the changes in the economic system and practices, the rising nationalism, geographical exploration movement and colonization, and the American Revolution which resulted in the establishment of an independent English-speaking state (Millward \& Hayes, 2012; Crystal, 2002). "However," Davies (2013) argued that, "if there was one event that was to have a more profound effect on English than any other, it was probably the establishment in London of William Caxton's printing press in 1476 and the subsequent publication of books and translations in English" (pp. 28-29). The introduction and dissemination of the printing press led to the standardization of the spelling system of English (Winkler, 2007) and allowed writers to produce their literary works in their people's dialects (Baugh \& Cable, 2002). However, "the pace of the English language history quickens" (Crystal, 2002, p. 207) for more change, growth, and expansion.

It is worth mentioning that the other events during the Early Modern period had also left a significant impact on English's internal and external history by consolidating the changes in the language in terms of structure, use, and status. At one time in the stage of its development, English took the steps of exploring new territories beyond its national geographical boundaries, to which it was confined until 1558 (Millward \& Hayes, 2012; Baugh \& Cable, 2002). Algeo and Pyles (2010) observed that "The sixteenth to eighteenth centuries were a time of revolutionary development, opening the way for English to become a world language" (p. 139) that would eventually spread and dominate many domains and practices. According to Crystal (2002), "The most significant step in the progress of English towards its status as a world language took place in the last decades of the sixteenth century, with the arrival of the expeditions commissioned by Walter Raleigh to the 'New World"' (p. 24). This stage in the history of English is crucial because the language did not only change in its structure and status, but it also shaped the entire global linguistic situation (see Salih \& Holi, 2018).

\subsection{Global Englishes}

The recent emergence of globalized English and its triumph and dominance in the international arena have caught the researchers' attention and sparked debate among them. Baugh and Cable (2013) observed that "It was only in the mid-twentieth century that scholars of the language began constructing models to describe the place of English in the world" (p. 397). According to Kachru (2008), the concept "world Englishes", and the spread of the English language as a global language phenomenon, is better contextualized if the diasporic locations of the language are related to the colonial expansion of the British empire" (p. 567) with which English expanded in land and use. According to Millward and Hayes (2012), "within the next hundred years, the English were to acquire such far-flung colonies as Bermuda, Jamaica, the Bahamas, British Honduras, the Leeward Islands, Barbados, the Mosquito Coast, Canada, the American colonies, India, St. Helena, Gambia, and the Gold Coast" (p. 222) - an expansion seen by Kachru as "the glorious period of the British Raj, that the sun never set on the Empire, and now never sets on the English language" (pp. 567-568), marking another different phase of change and growth of the language in culturally and linguistically diversified contexts. Moreover, "These distinctly different contexts of linguistic ecology opened up", according to Kachru, "theoretically and methodologically, challenging research areas in language contact and convergence and multilingual interactions" (p. 568).

Colonization was an event that brought English into closer contact with many local languages in these colonies, earning more contexts for the breed of many varieties of English other than the two known national varieties, namely British English and American English. The idea suggested here is that "As a remarkable development, the aftermath of colonization and internationalization of English is not realized in the only two national varieties of English: the British English and later the American English, but as 'Englishes"” (Salih \& Holi, 2018, p. 100). The distribution of English in the global context is further described by Kachru, who developed a conceptual framework in terms of concentric circles model representing different forms of English presence and contexts as the following excerpt illustrates: 
the inner circle of the predominantly English-speaking countries; the outer circle of the former colonies where English is an official language; and the expanding circle where, although English is neither an official nor a former colonial language, it is increasingly part of many people's daily lives (Cook, 2003, p. 27).

According to Kachru (2008), "The model presents a schema for historical, educational, political, social, and literary contextualization of the English language with reference to its gradual - and unprecedented - expansion with the ascendancy of the British Raj and later in the post-colonial period" (p. 568). Kachru's concentric circles model for the global distribution of English challenges researchers to examine globalized English beyond the ESL/EFL contexts. We need to understand better the current status of these emerging varieties and their role in the continuation, and possibly the future, of global English. Globalized English is a result of the influences of many decisive factors which play vital roles in its proliferation, triumph, and application, as illustrated in the following excerpt:

In addition to its four hundred million or so first-language speakers, and over a billion people who live in a country where it is an official language, English is now taught as the main foreign language in virtually every country, and used for business, education, and access to information by a substantial proportion of the world's population (Cook, 2003, p. 25).

Linguists used different terms to describe the phenomenal global spread and dominance of English. These include: "English as a global language" (e.g., Crystal, 2002, 1997), "English as a lingua franca" (ELF) (e.g., Seidlhofer, 2004; Cook, 2003), "English as an international language (EIL)" (e.g., Davies, 2013; Jenkins, 2000), and "English as a world language" (e.g., Mair, 2003; Baugh \& Cable, 2002). These terms explain English's current global status as a language learned and used by native speakers of different languages who learn it and use it for varieties of reasons and goals. English as an international lingua franca is a linguistic phenomenon that is receiving growing attention from researchers. There are relentless attempts to examine its various aspects, including its linguistic features, the characteristics of its users, and its role in international higher education (e.g., Jenkins, 2014, 2002, 2000; McKay, 2002; Seidlhofer, 2004; Mackenzie, 2014). Also, the launch of the Vienna-Oxford International Corpus of English (VOICE) project in 2009 acknowledged the growing significance of global English as stated in the project's website:

In the early 21st century, English in the world finds itself in an "unstable equilibrium": On the one hand, the majority of the world's English users are not native speakers of the language, but use it as an additional language, as a convenient means for communicative interactions that cannot be conducted in their mother tongues. On the other hand, linguistic descriptions have predominantly been focusing on English as it is spoken and written by its native speakers. https://www.univie.ac.at/voice/

VOICE states that it "seeks to redress the balance by providing a sizeable, computer-readable corpus of English as it is spoken by this non-native speaking majority of users in different contexts", since "These speakers use English successfully on a daily basis all over the world, in their personal, professional or academic lives". This realization made Baugh and Cable (2002) argue that "The extent and importance of the English language today made it reasonable to ask whether we cannot speculate the possible position it will occupy in the future" (p. 5). The present study is an attempt to address such a question.

\section{The Future of English: Where is the Language Heading to?}

The growth and rise of English to international fame is an interesting linguistic phenomenon that reflects the culmination of the implications of political, economic, social, cultural, technological, and scientific factors that fostered the globalization of English. The triumph of English as an international language makes it a language of significant status. Baugh and Cable (2002) argued that "In numbers of speakers as well as in its uses for international communication and in other less quantifiable measures, English is one of the most important languages of the world" (p. 4). Moreover, the English language has acquired importance and received researchers' extensive attention as well. According to Schreier et al. (2009) "Given the fact that hundreds if not thousands of languages around the world are barely documented or simply not researched at all, the massive body of research on English seems truly without parallel" (p. 1). The massive volume of research available now about English results from the various approaches and perspectives researchers embraced in studying its history, linguistic evolution, and the implications of its spread and dominance. Thus, historical and comparative linguistics, colonization and varieties of English, creolization and pidginization of English, English and imperialism, culture and literature, as well as applied linguistics are all different perspectives used by researchers in studying the changes that have taken place in different stages, particularly in assessing the current status of English (Mesthrie \& Bhatt, 2008). These studies have provided rich data on the impact of varieties of factors that 
have played significant roles in transforming the linguistic system of English and the consequences of its changes and dominance on the world's linguistic map. Besides, with these studies, there is a growing strand of academic concern about the English language tomorrow.

\subsection{The Future of English and Its Varieties}

Because of its peculiarity, the modern time in English language history is the right point to evaluate the situation and predict what will happen to this language and its varieties or Englishes. Thus, it is legitimate to assess the current linguistic situation by considering all the influences and circumstances that may determine the future of the English language and its varieties. The topic is challenging and as divisive as its significance, especially when we realize that "The role of English has developed to such an extent, unprecedented in world history, that it is difficult to see how it can now be dislodged" (Crystal, 2002, p. 293). English is envisaged to continue to dominate the international arena because "Few people doubt that English, having come this far, will continue to be used as a global language" (Davies, 2013, p. 148). In any attempt to predict the future of any natural human language, several decisive factors should be taken into consideration. In this context, Baugh and Cable (2013) argued that "The variables to be considered come from demographics, economics, second-language learning, language complexity, and the histories of the languages concerned, including the developments of their writing systems" (p. 397). The above-stated factors, among other unseen or unpredictable variables, determine the future of any language. In the English language context, particularly its current status, these factors are of significant relevance, especially when it comes to its future. Anticipating what will happen next to English is undoubtedly as important as describing its linguistic evolution principles. In this context, Baugh and Cable $(2013,2002)$ listed several challenges they considered parameters to be used to predict the future of English. These variables are as follows:

1. The actual size of the English-speaking population.

2. Changing scenes, conditions, and realities because "A repetition of the spread of a language by conquest is unlikely in the twenty-first century" (Baugh \& Cable, 2013, p. 399).

3. The rise of Chinese and its soft approach in spreading and acquiring new territories by way of economic incentives and cooperation.

4. Emerging research trends in first and second language acquisition concerning difficulty in learning which might promote learning of languages like Chinese.

Winkler (2007) remarked that "Numerous predictions have been made about what could happen to English because of its status as a continually growing global language" (314). Other linguists such as Davies (2013) and Crystal (2002) have joined Winkler to draw the different scenarios that await the English language. The following sections highlight these predictions concerning the future of English as an international language.

\subsubsection{Growing English-Speaking Population}

In attempting to predict the future of English as an international language, the number of people using it is taken into account as a determinant factor "Since growth in a language is a matter of population" (Baugh \& Cable, 2002, p. 5). Recent statistics reveal that the 400 million or so-population of English speakers as a first language is superseded by its ESL or EFL users. Thus, it is anticipated that with English growing big in population size, it could turn into a 'monster' that leads to the death of many vulnerable languages with a smaller number of speakers.

\subsubsection{English and Language Variation}

Another scenario that awaits English is related to the process of variation and change. The future of English is suggested to witness the birth of more varieties that will eventually become subject to change. Thus, English, like Latin, might produce more varieties that would eventually develop into distinct codes.

\subsubsection{More Globalization}

Another prediction suggests that English will continue to grow as a global language for more dominance and expansion, especially with the growing populations of the people who use English in the outer and expanding circles. However, Davies (2013) argued that the spread of English as a lingua franca might be hindered by the local varieties of English actively used in these circles. In studying the spread of English as an international lingua franca and its future, it is of paramount importance that research broadens our understanding of the linguistic features of the varieties and the attitudes towards them. In addition, the lesser-known varieties of English need further attention from researchers. 


\subsubsection{Threats to English}

Davies (2013), citing McKay (2002), reported that the proliferation of globalized English might be challenged by many hurdles that include the changing geopolitical circumstances and conditions and attitudes towards English in the outer and expanding circles. The Global spread of English could face serious drawbacks if the outer or expanding circles redefine their relationship with the inner circle and opt for more autonomy and less dependence on the latter. Besides, English as an international language is likely to be affected by the rising demands for more recognition of minority groups in the educational systems of some nations and the "predictions that the percentage of material stored on the Internet in English may fall from 80 per cent to about 40 percent of the total information" (Davies, 2013, p. 148). The prediction about the drop in English dominance as the Internet's language to only a half suggests that the world will witness more multilingual web-based information. Such a change is anticipated to give rise to more languages to compete with English on the Internet.

The predictions about the future of English as an international language are challenged by the facts on the ground concerning the prevalent bilingualism and multilingualism worldwide, the intelligibility of English varieties, and the smooth computer-mediated communication as a common phenomenon among speakers of Englishes honed by the modern media.

\subsection{On an Applied Linguistic Perspective}

The study of the growth and spread of the English language, as an academic topic, reveals the emergence of two views. On the one hand, there are those who believe that English will continue to dominate and prosper as a global language because, "Certainly the signs are that no other language will replace it in this role in the foreseeable future, though other languages may have increasing influence in trade and communications in particular regions of the world (e.g., Spanish in the Americas)" (Davies, 2013, p. 148). Also, Crystal (2002) remarked that "At present, due primarily to the economic superiority of the United States, there is no competitor for English as a world language" (p. 281). On the other hand, there are some who look at the spread of English with some anxiety and uncertainty about its future.

The circumstances indicate that global English will continue to face challenges, especially if the factors that led to its rise and triumph face unprecedented decline. According to Davies (2013), Kachru's concentric circle model reveals the manner in which English has spread in three different contexts, where it spreads "in the Inner Circle largely through migration of English speakers; in the Outer Circle largely through colonisation by English-speaking nations and in the Expanding Circle through foreign language teaching" (p. 141). The different circumstances that contributed to the spread of English and brought its varieties into existence, such as migration of English speakers or colonization, might not be available or continue to sustain the language. The crux of the matter is that the global distribution of English has created an unprecedented situation accompanied by the complexities of political, economic, cultural, technological, scientific, and social factors. In this situation, English faces various challenges as well as external and internal threats that might undermine its global dominance and lead. Moreover, since the language has a pivotal role in the life activities of millions of people around the globe, and because it is involved in activities and situations where decisions are needed to be made, this makes applied linguistics the appropriate discipline that can examine the future of English and its varieties and provide sound advice and practical solutions. According to Cook (2003), applied linguistics should look urgently at the rise and rapid growth of English as a lingua franca and its future, especially with the understanding of applied linguistics today as "the academic discipline concerned with the relation of knowledge about language to decision making in the real world" (p. 5). Thus, the perspective applied linguistics provides relates to assessing the consequences of the globalization of English on its users' lives around the world. In addition, applied linguistics may answer the questions of the future of English and its varieties vis-à-vis its users' experience. The shift of trends in linguistics promotes the applied linguistics perspective as the most appropriate for examining issues concerning the rise of global English. Davies (2013) remarked that traditionally, the task of "linguistics was to focus almost entirely on the forms or structures of language, whereas today there is far more emphasis on how and why people use language in particular ways, and on the dynamic interrelationship between language and communicative function" (p. 1).

\section{Concluding Remarks}

Throughout its history, the English language has demonstrated a remarkable ability for adapting to changes and tremendous flexibility in dealing with circumstances of various types. The English language has benefited from all the principles and factors behind its linguistic evolution. The rise of English as an international lingua franca is a linguistic phenomenon that shows the triumph of English as an academic subject that catches researchers' attention. Moreover, because the language is growing and expanding in different contexts and conditions, it is 
imperative to provide different perspectives and conceptual interests in studying its history and its future use. This is necessary because English is not changing for its own sake; it is rather changing and growing to influence people worldwide, whether learners, users, or researchers (Jenkins, 2014). However, despite its comprehensive coverage of English's linguistic development from its arrival at the British Isles until today, historical linguistics did not attempt to question critically and thoroughly the implications of the internationalization of English on people's lives. Moreover, because applied linguistics is the discipline that investigates the development of English in the context of its users' experience, it is legitimate to explore and develop theoretical considerations of its growth and future. More research is needed to provide new paradigms for exploring the interaction between different varieties of English in the global context with particular reference to the language learning domain. The matter is complicated as we need to know first what characteristics English(es) speakers have, especially in light of the call or redefining the traditional concept of a native speaker of English. This new situation and the new realities created by the current situation of English require new features that signify English, its function, structure and users as well. We need more research to broaden our understanding of the distribution of languages and see whether the conventional categorization of world's major languages has changed and the impact of that on the destiny of the English language itself.

\section{References}

Algeo, J., \& Pyles, T. (2010). The origins and development of the English language (6th ed.). Boston: WADSWORTH CENGAGE Learning.

Baugh, A. C., \& Cable, T. (2002). A history of the English Language (5th ed.). USA: Routledge.

Baugh, A. C., \& Cable, T. (2013). A history of the English Language (6th ed.). London: Routledge.

Brutt-Griffler, J. (2002). World English: A study of its development. UK: Multilingual Matters Ltd. https://doi.org/10.21832/9781853595790

Chamonikolasová, J. (2014). A concise history of English. Brno: Masarykova univerzita.

Cook, G. (2003). Applied linguistics. Oxford: Oxford University Press.

Crystal, D. (1997). English as a global language. Cambridge: Cambridge University Press.

Crystal, D. (2002). The English language: A guided tour of the language. London: Penguin Books.

Culpeper, J. (2005). History of English. London: Routledge. https://doi.org/10.4324/9780203023501

Davies, D. (2013). Varieties of modern English: An introduction. London: Routledge Taylor \& Francis Group. https://doi.org/10.4324/9781315838861

Finegan, E. (2004). Language: Its structure and use (4th ed.). USA: Thomson Wadsworth.

Formkin, V., Rodman, R., \& Hyams, N. (2011). An introduction to language (9th ed.). United Kingdom: Wadsworth, Cengage Learning.

Harrison, D. K. (2007). When languages die: The extinction of the world's languages and the erosion of human knowledge. Oxford: Oxford University Press. https://doi.org/10.1093/acprof:oso/9780195181920.001.0001

Jenkins, J. (2000). The phonology of English as an international language: New models, new norms, new goals. (Oxford Applied Linguistics). Oxford, GB: Oxford University Press.

Jenkins, J. (2002). A sociolinguistically based, empirically researched pronunciation syllabus for English as an international language. Applied Linguistics, 23(1), 83-103. https://doi.org/10.1093/applin/23.1.83

Jenkins, J. (2014). English as a lingua franca in the international university. New York: Routledge. https://doi.org/10.4324/9780203798157

Kachru, B. (2008). World Englishes in world contexts. In H. Momma \& M. Matto (Eds.), A Companion to the History of the English Language (pp. 567-580). Blackwell. https://doi.org/10.1002/9781444302851.ch55

Mackenzie, I. (2014). English as a lingua franca: theorizing and teaching English. London: Routledge Taylor \& Francis Group. https://doi.org/10.4324/9781315890081

Mair, C. (Ed.). (2003). The politics of English as a world language: New horizons in postcolonial cultural studies. Amsterdam: Rodopi.

McKay, S. L. (2002). Teaching English as an international language. Oxford: Oxford University Press.

Mesthrie, R., \& Bhatt, R. M. (2008). World Englishes: The study of new linguistic varieties. Cambridge: Cambridge University Press. https://doi.org/10.1017/CBO9780511791321 
Millward, C., \& Hayes, M. (2012). A biography of the English language. USA: WADSWORTH CENGAGE Learning.

Richards, J. C., \& Schmidt, R. (2002). Longman dictionary of language teaching and applied linguistics (3rd ed.). London: Longman Pearson Education.

Salih, A. A., \& Ali, H. H. (2018). English language and the changing linguistic landscape: New trends in ELT classrooms. Arab World English Journal (AWEJ), 9(1), 97-107. https://doi.org/10.24093/awej/vol9no1.7

Schreier, D., Trudgill, P., Schneider, E. D., \& Williams, J. P. (Eds.). (2009). The lesser-known varieties of English: An introduction. Cambridge: Cambridge University Press. https://doi.org/10.1017/CBO9780511676529

Seidlhofer, B. (2004). Research perspectives on teaching English as lingua franca. Annual Review of Applied Linguistics, 24, 209-239. https://doi.org/10.1017/S0267190504000145

The Vienna-Oxford International Corpus of English (VOICE). Retrieved from https://www.univie.ac.at/voice/

Trask, R. (1994). Language change. London: Routledge.

Trask, R. (2010). Why do languages change? Cambridge: Cambridge University Press. https://doi.org/10.1017/CBO9780511841194

Winkler, E. (2017). Understanding language. London: Continuum.

\section{Copyrights}

Copyright for this article is retained by the author(s), with first publication rights granted to the journal.

This is an open-access article distributed under the terms and conditions of the Creative Commons Attribution license (http://creativecommons.org/licenses/by/4.0/). 